\title{
Antifouling activity and microbial diversity of two congeneric sponges Callyspongia spp. from Hong Kong and the Bahamas
}

\author{
P. Y. Qian ${ }^{1, *}$, S. Dobretsov ${ }^{1}$, H. U. Dahms ${ }^{1}$, J. Pawlik ${ }^{2}$ \\ ${ }^{1}$ Department of Biology and Coastal Marine Laboratory, Hong Kong University of Science and Technology, Clear Water Bay, \\ Kowloon, Hong Kong SAR, PR China \\ ${ }^{2}$ Center for Marine Science, University of North Carolina Wilmington, 5600 Masonboro Loop Road, Wilmington, \\ North Carolina 28409, USA
}

\begin{abstract}
Microbial communities of the sponges Callyspongia sp. from Hong Kong and Callyspongia plicifera (Porifera: Demospongia) from the Bahamas were compared with each other and with those from reference substrata using a terminal restriction fragment length polymorphism (T-RFLP) analysis. The least number of bacterial ribotypes and bacterial isolates were retrieved from Bahamas reference and sponge surfaces, while the bacterial communities from Hong Kong Callyspongia sp. and reference surfaces were more diverse. Microbial communities from the 2 sponges were different from each other and from reference substrata. Gas chromatographic-mass spectrometric (GC-MS) analysis of dichloromethane extracts revealed that more than $60 \%$ of the compounds were similar in the 2 species Callyspongia sp. and C. plicifera, compared to the compounds of Halichondria spp. At tissue level (TL) concentrations, both sponge extracts predominantly inhibited the growth of bacteria from reference substrata. Multifactor ANOVA revealed that the source of bacteria (sponge surface, interior, or reference substrata), the geographic location of isolates (Hong Kong or the Bahamas), the sponge extract (from Callyspongia sp. or from C. plicifera), and combinations of these factors contributed significant effects in disc diffusion assay experiments. Sponge extracts at both TL concentrations and 10x dilutions were toxic to larvae of the polychaete Hydroides elegans and the barnacle Balanus amphitrite. Our results suggest that the 2 congeneric sponges Callyspongia spp. from different biogeographic regions have different bacterial associates, while producing relatively similar secondary metabolites. It remains to be explored whether differences in sponge-associated bacterial communities will also hold for other congeneric sponge species from different regions.
\end{abstract}

KEY WORDS: Sponge allelochemicals $\cdot$ Antifouling $\cdot$ Bacteria $\cdot$ Larvae $\cdot$ Microbial communities · Biogeographic comparison $\cdot$ South China Sea $\cdot$ Bahamas

\section{INTRODUCTION}

Marine sponges (Porifera) are associated with a remarkable array of microorganisms that comprise actinomycetes (Burja \& Hill 2001, Hill 2004) and other bacteria (Hentschel et al. 2001, Thoms et al. 2003), cyanobacteria (Thacker \& Starnes 2003), fungi (Sponga et al. 1999), dinoflagellates (Burja \& Hill 2001), and unicellular algae (Ruetzler 1985). These microorganisms are present on or inside most sponge species. Several investigations have shown that microbiota from sponges differ from those associated with adjacent reference substrata and seawater (Santavy \& Colwell 1990, Hentschel et al. 2002, Lee \& Qian 2004, Dobretsov et al. 2005a), suggesting that these associations are specific and, perhaps, symbiotic.

Similar bacterial isolates were found in distantly related species of sponges (Webster \& Hill 2001, Hentschel et al. 2002, Fieseler et al. 2004, Olson \& McCarthy 2005). For example, Hentschel et al. (2002) demon- 
strated that the sponges Aplysina aerophoba and Theonella swinhoei from the Mediterranean Sea, Red Sea and Pacific Ocean have a uniform microbial community that is phylogenetically different from that of marine plankton and marine sediments (Hentschel et al. 2002). Chloroflexi spp. bacteria have been found to be specific to all Aplysina species (Hentschel et al. 2003). Moreover, 3 major groups of Actinobacteria have been found in 3 species of Xestospongia spp. from different oceans (Montalvo et al. 2005). In contrast, Taylor et al. (2005) recently demonstrated that bacterial communities associated with the sponge Cymbastela concentrica from tropical waters differed from those in temperate Australia. However, the specificity of microbial associations from congeneric sponge hosts from different oceans and the specificity of bioactive metabolites from sponges remain largely unexplored.

Marine sponges are a rich source of unique and diverse bioactive metabolites (Faulkner 2000, Blunt et al. 2003). Many sponge- or sponge-symbiont-derived metabolites are potent antibacterial, antifungal, antifeeding or antifouling compounds (Beccerro et al. 1997, Davis 1998, Bakus et al. 1986). Cytotoxic (Toth \& Schmitz 1994), antibiotic (Wang et al. 1996) and antifouling (Tsukamoto et al. 1997) compounds were previously isolated from different representatives of Callyspongia spp. It has also been suggested that chemical defenses from tropical and temperate congeneric species of sponges are similarly strong and effective against predators (Becerro et al. 2003).

In this study we investigated the microbial community associated with 2 congeneric sponges Callyspongia spp. from the tropical western Atlantic (the Bahamas) and the western Pacific (Hong Kong) and tested the bioactivity of their extracts. Our objectives were specifically to: (1) compare the bacterial communities of 2 congeneric Callyspongia species and adjacent substrata, (2) compare the chemical profiles of dichloromethane extracts of these species with other sponge species, (3) examine the effects of crude extracts of these species on the growth of marine bacteria isolated from both sponges and from adjacent reference substrata, and (4) examine the effects of crude extracts on the larval attachment of dominant foulers in tropical waters-the polychaete Hydroides elegans and the barnacle Balanus (Balanus) amphitrite.

\section{MATERIALS AND METHODS}

Collection of sponges. Specimens of the sponge Callyspongia sp. were collected from Hong Kong at depths of 1 to $3 \mathrm{~m}$, at the pier next to the Coastal Marine Laboratory (CML) of the Hong Kong University of Science and Technology $\left(22^{\circ} 22^{\prime} \mathrm{N}, 114^{\circ} 16^{\prime} \mathrm{E}\right)$ in
August 2004. In their natural habitats, these yellowwhite solitary sponges are free from fouling and attach to underwater structures of the pier, and are surrounded by clumps of oysters. The sponges were identified by Prof. Rob van Soest, and voucher specimens were placed in the Zoological Museum of Amsterdam under the archive number ZMAPOR 17598. The sponge Callyspongia plicifera (Lamarck, 1814) was collected from Great Stirrup Cay, Bahama Islands $\left(25^{\circ} 51^{\prime} \mathrm{N}, 77^{\circ} 53^{\prime} \mathrm{W}\right)$ at a depth of about $5 \mathrm{~m}$ during a field survey conducted by the research vessel RV 'Steward Johnson I' from the Harbor Branch Oceanographic Institution, Florida, in July 2003. These fluorescent-blue or purple-pink sponges have no biofouling and inhabit coral reefs. The sponge $C$. plicifera can grow solitarily or in groups. For the chemical comparison of crude extracts (see below), the sponge Halichondria sp. (ZMAPOR 17603) was collected from Hong Kong waters from the same pier next to the CML and the sponge $H$. melanodocia was collected from Great Stirrup Cay, Bahama Islands.

In all cases, sponges were carefully brought to the water surface by SCUBA divers and transferred to large buckets. Wet weight was measured and the tissue volume was determined by water displacement in a graduated cylinder filled with seawater.

Bacterial isolation. Prior to the isolation of bacteria the sponges were soaked several times in autoclaved $0.22 \mu \mathrm{m}$-filtered seawater (AFSW) in order to wash away bacteria that were not associated with sponges and might represent contaminants from the water column. The outer surfaces of 6 sponges were swabbed with 5 separate sterile cotton balls for the collection of cultivable epibiotic bacteria. To collect bacteria from the sponge interior, sponges were cut with a sterile scalpel and internal surfaces were swabbed with sterile cotton balls. Three sample swabs from 5 sponge individuals were combined and suspended in AFSW from the location of each species (Hong Kong or the Bahamas) and from the sponge exterior and interior. Bacterial suspensions were diluted ( 0.1 and $0.01 \times)$ in AFSW. Aliquots of $200 \mu \mathrm{l}$ of each suspension were streaked onto nutrient agar (composed of $1.5 \%$ agar in $0.22 \mu \mathrm{m}$ filtered seawater (FSW), $0.3 \%$ yeast extract, $0.5 \%$ peptone) with replication $(\mathrm{n}=3)$ and incubated at $30 \pm 1^{\circ} \mathrm{C}$ under a $15: 9 \mathrm{~h}$ light:dark photoperiod. After 1 to $3 \mathrm{~d}$ of incubation, bacterial colonies were examined under a dissecting microscope for conspicuous characteristics such as colour, shape, size, surface topography, and the presence of granules. Distinguishable colonies were isolated and purified. Bacteria were also isolated from reference substrata (stones and shells) within a range of $0.5 \mathrm{~m}$ of the sponges. These bacterial isolates were stored in $50 \%$ glycerol at $-80^{\circ} \mathrm{C}$. Bacterial strains were identified by compara- 
tive analysis of their 16S rRNA gene sequences as described in Lau et al. (2002). The primers used in the PCR were 355F forward (5'-ACTCCTACGGGAGGCAGC-3') (Amann et al. 1990), 1055R reversal (5'CACGAGCTGACGACAGCCAT-3') (Lee et al. 1993), 926F forward (5'-CCGTCAATTCCTTTRAGTTT-3') (Lee et al. 1993) and 1492R reversal (5'-GGYTACCCTGTTACGACTT-3') (Eden et al. 1991). Fragments of DNA sequences obtained from individual primers were assembled using the Sequencher® software package (Gene Codes). The closest match to the $16 \mathrm{~S}$ rRNA gene sequence of the respective bacterium was retrieved by comparison with data from GenBank (www.ncbi.nlm.nih.gov). The extent of similarity between the bacterial isolate sequence and a GenBank close match sequence was based on the percent of sequence identity.

Bacterial communities of the sponges and adjacent surfaces. In order to compare bacterial communities, 3 outer and inner surfaces $\left(20 \mathrm{~cm}^{2}\right)$ of the sponge and 3 outer surfaces of reference substrata (stones in close proximity to the sponge) were swabbed with sterile cotton balls following the method described by Lee \& Qian (2004). After each swab the cotton balls were individually suspended in $1 \mathrm{ml}$ extraction buffer (100 mM Tris-HCl, 100 mM EDTA, 100 mM sodium phosphate, $1.5 \mathrm{M}$ sodium chloride, $1 \% \mathrm{CTAB}$; at $\mathrm{pH}$ 8) in $2 \mathrm{ml}$ micro-centrifuge tubes. The samples were lysed by 3 cycles of freezing and thawing followed by $2 \mathrm{~h}$ incubation in $20 \%$ sodium dodecylsulfate (SDS) at $65^{\circ} \mathrm{C}$. The cotton balls were removed and after centrifugation $\left(10000 \mathrm{rpm} \times 5 \mathrm{~min}^{-1}\right)$, the total DNA in the supernatant was extracted and purified in a volume of 24:1 chloroform:isoamyl-alcohol, followed by precipitation in isopropanol at room temperature for $15 \mathrm{~min}$. The precipitated DNA was washed with cold $\left(-20^{\circ} \mathrm{C}\right) 70 \%$ ethanol, dried and re-suspended in $50 \mu \mathrm{l}$ of autoclaved double-distilled water and frozen until use.

Polymerase chain reaction (PCR) of 16S rRNA genes of bacterial communities was performed in a total volume of $25 \mu \mathrm{l}$ containing $1 \mu \mathrm{l}$ of DNA template, $250 \mu \mathrm{M}$ of each desoxyribonucleotide triphosphate (dATP, dCTP, dGTP, dTTP; Pharmacia Biotechnology), 1 U of DNA Taq polymerase (Amersham Biosciences) and $0.8 \mu \mathrm{M}$ of each universal primer: $341 \mathrm{~F}$ forward $\left(5^{\prime}-\right.$ CCTACGGGAGGCAGCAG-3') and 926R reversal (5' CCGTCAATTCCTTTRAGTTT-3') (Amann et al. 1990, Lee et al. 1993). The 926R primer was labeled at the 5'end with 6-carboxy fluorescein (FAM) dye. The thermocycling conditions were as follows: $95^{\circ} \mathrm{C}$ for $2 \mathrm{~min}$ (1 cycle); $95^{\circ} \mathrm{C}$ for $30 \mathrm{~s}(15$ cycles $), 60^{\circ} \mathrm{C}$ for $3 \mathrm{~min}$ and $72^{\circ} \mathrm{C}$ for $3 \mathrm{~min}$. The annealing temperature started at $60^{\circ} \mathrm{C}$ and was reduced to $45^{\circ} \mathrm{C}$ in increments of $1^{\circ} \mathrm{C}$ cycle $^{-1} ; 10$ cycles of $95^{\circ} \mathrm{C}$ for $30 \mathrm{~s}, 45^{\circ} \mathrm{C}$ for $3 \mathrm{~min}$ and $72^{\circ} \mathrm{C}$ for $3 \mathrm{~min}$; and $72^{\circ} \mathrm{C}$ for $10 \mathrm{~min}$. Amplified DNA ( $4 \mathrm{\mu l}$ of PCR mixtures) was visualized by gel electrophoresis on a $1.5 \%$ agarose gel in Tris-acetate-EDTA (TAE) buffer.

Fluorescently labeled PCR products were purified with the Wizard® PCR preps DNA purification system (Promega) according to the manufacturer's protocol. Purified amplicons were digested with $20 \mathrm{U}$ MspI (Boehringer Mannheim Biochemicals) at $37^{\circ} \mathrm{C}$ for $6 \mathrm{~h}$. Aliquots of digested products $(10 \mu \mathrm{l})$ were mixed with $0.5 \mu \mu \mathrm{l}$ of internal size standard (ET550-R, Amersham Biosciences). This mixture was denatured for 2 min at $95^{\circ} \mathrm{C}$ and immediately chilled on ice prior to capillary electrophoresis on a MegaBACE ${ }^{\mathrm{TM}}$ genetic analyzer (Amersham Biosciences) operated in the genotyping mode. After electrophoresis, the lengths of the fluorescently labeled terminal restriction fragments (T-RFs) were determined by comparison with internal size standards using the 'Fragment Profiler' software (Amersham Biosciences). The lengths of T-RFs obtained by the analyzer were rounded up to the nearest integral values. Peaks that were less than $1.5 \mathrm{bp}$ apart from a larger peak were classified as its 'shoulders' and thus eliminated (Dunbar et al. 2001). For each sample, peaks over a threshold of 50 fluorescence units (Blackwood et al. 2003) and whose peak heights contributed at least $1 \%$ to the integrated height (Buchan et al. 2003, Luna et al. 2005) were used for analysis. Terminal fragments $<35 \mathrm{bp}$ and $>500 \mathrm{bp}$ were excluded from the analysis to avoid detection of primers and uncertainties of size determination. In order to relate 16S rRNA sequences of isolates with the length of particular T-RFLP peaks, we used NEBcutter analysis (http://tools.neb.com/NEBcutter2/index.php) that allowed us to mimic the digestion of the rRNA sequence by the $M s p I$ enzyme.

Extraction of sponges and chemical profiles of sponge extracts. In the laboratory, 5 sponge specimens belonging to the same species (Callyspongia sp., $C$. plicifera, Halichondria sp. or $H$. melanodocia) were combined together and extracted 3 times with dichloromethane (DCM) for $8 \mathrm{~h}$ by gentle agitation. The extracts were filtered through a paper filter (Whatman No. 1) and concentrated by rotary evaporation to a concentration that represented $10 \times$ tissue level (TL). In the case of Callyspongia sp. and C. plicifera, the concentration of crude extracts was adjusted prior to each experiment (see below). Prior to larval bioassay experiments, extracts were evaporated until dry, and subsequently re-dissolved in dimethyl sulfoxide (DMSO) (Sigma). Before the experiments, extracts were mixed with AFSW and screened at TL (1×), 10-fold stronger $(10 \times)$ (disk diffusion bioassay), 10-fold weaker $(0.1 \times)$ and 100-fold weaker (0.01×) (larval bioassay) concentrations. 
Crude extracts of Callyspongia sp. and Halichondria sp. from Hong Kong, and C. plicifera and H. melanodocia from the Bahamas were dried under vacuum, re-dissolved in DCM and subsequently separated and analyzed by coupled gas chromatography-mass spectrometry (GC-MS) with electron impact ionization (Varian CP-3800, ion trap Varian-2200). GC-MS separations were performed on relatively non-polar capillary columns (CP-Sil 8 CB-MS, 30 m length, $0.25 \mu \mathrm{m}$ film thickness, $0.25 \mathrm{~mm}$ i.d.). The injection port was held at $275^{\circ} \mathrm{C}$ and the interface at $300^{\circ} \mathrm{C}$. The temperature was programmed from $75^{\circ} \mathrm{C}$ to $310^{\circ} \mathrm{C}$ at $10^{\circ} \mathrm{C}$ $\mathrm{min}^{-1}$. Helium was used as the carrier gas. Each peak on a chromatogram represents an individual compound that was separated from the extract. In order to identify compounds from extracts we used the National Institute of Standards and Technology (NIST) GC-MS library. The library compares mass spectra of unknown individual compounds with those in the library. The closest match (with the highest probability) to the library was recorded. Peaks over a threshold of $20 \mathrm{k}$ counts were used for the analysis. DCM was used as a control and peaks that appeared on the control chromatogram were excluded from the analysis.

Antibacterial assay. In order to investigate antibacterial effects of sponge extracts from the Hong Kong sponge Callyspongia sp. and the Caribbean sponge $C$. plicifera, DCM extracts at $1 \times$ and $10 \times$ TL concentrations were pipetted onto circular paper discs (Whatman No. 1; disc volume $20 \mu \mathrm{l}$ ). An additional set of discs loaded with $40 \mu \mathrm{g} \mathrm{disc}^{-1}$ of streptomycin and with $20 \mu \mathrm{l}$ DCM were used as an antibiotic control and a solvent control correspondingly. Each bacterial strain was inoculated onto agar plates, and the dried discs, either with the sponge extracts or with the controls, were then placed onto the plates. Agar plates were incubated for $24 \mathrm{~h}$ at $30^{\circ} \mathrm{C}$. The experiments were performed with 5 replicates. The observed zones of growth inhibition between the disc and the bacterial film were measured to the nearest $0.2 \mathrm{~mm}$ by a stereomicroscopic inspection.

Larval bioassays. Adults of the tubeworm Hydroides elegans (Haswell) were collected from submerged rafts of the fish farm at Wong Shek, Hong Kong $\left(22^{\circ}\right.$ $\left.25^{\prime} \mathrm{N}, 114^{\circ} 20^{\prime} \mathrm{E}\right)$. Larval cultures were prepared and maintained according to Bryan et al. (1997). Only competent larvae were included in the bioassays. Metamorphic competence of $H$. elegans larvae was determined by their characteristic morphology and by a competency bioassay with the larval attachment stimulator 3-isobutyl-1-methylxanthine (IBMX, Fluka) at $10^{-4} \mathrm{M}$ in AFSW (Lau \& Qian 1997, Pechenik \& Qian 1998).

Adults of the barnacle Balanus amphitrite (Pitombo) were collected from stones at Marina Cove $\left(22^{\circ} 21^{\prime} \mathrm{N}\right.$, $\left.114^{\circ} 17^{\prime} E\right)$. Standard procedures were used to obtain and rear $B$. amphitrite larvae (Thiyagarajan et al. 2002). Nauplii were reared in batch cultures on a mixed diet (1:1) of Chaetoceros gracilis Schutt (LB 2658, UTEX) and Skeletonema costatum (Greville) (CCMP 1332) at approximately 1000 larvae $1^{-1}$ AFSW. The initial algal concentration was set at $2.5 \times 10^{5}$ cells $\mathrm{ml}^{-1}$ and kept constant subsequently. Cyprids were aged for $4 \mathrm{~d}$ in darkness at $8^{\circ} \mathrm{C}$ prior to attachment bioassays (Rittschof et al. 1992).

Each larval bioassay was conducted with replication ( $\mathrm{n}=6$ ) in multi-well polystyrene dishes (\#3047, Falcon) containing sponge extracts ( $1 \times$ or $10 \times$ concentrations) and 20 larvae of Hydroides elegans or Balanus amphitrite. Multi-well dishes filled with $1 \mathrm{ml}$ AFSW and containing $4 \%$ DMSO solution were used as controls. The IBMX (Fluka) at $10^{-4} \mathrm{M}$ in FSW was used as an artificial stimulator of larval attachment for $H$. elegans (Dobretsov \& Qian 2002). Hydroides elegans larvae were pre-treated with $10^{-4} \mathrm{M}$ IBMX for $30 \mathrm{~min}$ and then used for the larval bioassay. Both larval attachment assays were run at $24^{\circ} \mathrm{C}$ under continuous illumination for $24 \mathrm{~h}$. After this period of time, swimming, attached, and dead larvae were counted using a dissecting-microscope.

Statistical analysis. The diameter of inhibition zones of bacterial growth produced by different sponge extracts were square-root transformed prior to a multifactor ANOVA (Zar 1999) in order to investigate the effect of the extract source (Callyspongia sp. or $C$. plicifera), site of bacterial origin (sponge interior, exterior, or adjacent substratum), and geographic location (Hong Kong or the Bahamas) of isolates using results of the disk-diffusion bioassay. When no inhibition zone was produced, a value of 0.5 was given to improve normality of the data distribution (Zar 1999). For each larval bioassay, the differences between control and treatment were determined by a Dunnett's $t$-test (Zar 1999). Prior to this analysis the percentages of settled larvae and dead larvae were arcsine transformed (Zar 1999). In the cases of zero attached or dead larvae, a value of $1 / 4 \mathrm{n}$ ( $\mathrm{n}=$ number of larvae in a single replicate) was given to improve the normality of the data distribution (Zar 1999). In all cases, the normality assumption was verified by the Shapiro-Wilk test (Shapiro \& Wilk 1965). T-RF patterns of different bacterial community DNA samples were subjected to cluster analysis. BrayCurtis similarities were used to produce a similarity matrix based on the total number of T-RFs observed in all samples and the presence or absence of these T-RFs in individual samples. For the construction of a dendrogram demarcating the similarity of microbial communities in the gels, group average linkage in a hierarchical, agglomerative clustering algorithm was performed using the PRIMER program (Plymouth Marine Labora- 
tory) (Clarke \& Warwick 1994). Chemical profiles of sponges crude extracts were subjected to cluster analysis. We constructed a Bray-Curtis similarity matrix based on the total number of peaks presented in all extracts and the presence or absence of these T-RFs in individual samples. A dendrogram showing the similarity of crude extracts was constructed using the PRIMER program. In all cases, the threshold level for significance was $95 \%$.

\section{RESULTS}

\section{Bacterial isolates from sponges and reference substrata}

Only 7 bacterial strains were obtained from the exterior and interior of the Bahamas sponge Callyspongia plicifera and 9 strains from adjacent substrata (Table 1). Seven strains from the Bahamas sponges and from the adjacent substrata belonged to the $\gamma$-Proteobacteria group. Bacteria belonging to the Firmicutes group were found only among spongal isolates, and not from any of the nearby reference substrata from the Bahamas. One bacterial isolate from a Bahama reference surface belonged to the Schingobacteria group. Most of the bacteria from Hong Kong reference substrata belonged to the Firmicutes- and $\gamma$-Proteobacteria (Table 1). None of the bacterial isolates from reference substrata belonged to the $\gamma$-Proteobacteria or the Actinobacteria. Bacteria from the exterior and interior of Hong Kong Callyspongia sp. predominantly belonged to the $\gamma$-Proteobacteria.

\section{Bacterial communities associated with sponges and adjacent substrata}

The least number of bacterial ribotypes $(\mathrm{T}-\mathrm{RFs}=13$ to 22) were found on Bahamian samples, both from sponges and from adjacent substrata, while double the number of T-RFs (i.e. ribotypes) were found on Hong Kong samples (Table 2). Bacterial communities associated with sponges and reference substrata were characterized by the absence of certain ribotypes and the presence of other ribotypes (Table 2). Some T-RFs were unique to certain types of substrata (i.e. T-RF at $40 \mathrm{bp}$ in the Bahama reference, $431 \mathrm{bp}$ and $455 \mathrm{bp}$ in the Hong Kong reference; 176 bp, 307 bp for C. plicifera and $184 \mathrm{bp}, 199 \mathrm{bp}$ for Callyspongia sp.) or to certain locations (i.e. $422 \mathrm{bp}$ in the Bahamas, $47 \mathrm{bp}$ and 179 bp T-RFs in the Hong Kong samples). In contrast, T-RFs of $246 \mathrm{bp}$ were present in all substrata, suggesting that 1 or several bacterial species are widely distributed on a variety of different substrata and in different oceans. Both sponges showed unique T-RFs (i.e. $41 \mathrm{bp}, 310 \mathrm{bp}$ and $419 \mathrm{bp}$ ), suggesting that some bacteria are uniquely associated with certain sponge species.

NEBcutter analysis allowed us to correlate particular bacterial isolates with the presence of particular T-RFs. Most of the isolates did not match with any of the T-RFs. The T-RF (246 bp) that was present in all TRFLP profiles matched with the sequence of a Firmicutes sp. isolate (Hkr7) from the Hong Kong reference location. A T-RF of $199 \mathrm{bp}$ observed in Callyspongia sp. corresponded to the internal isolate (Hki9) from this sponge. A T-RF of $119 \mathrm{bp}$ that was present in all sponges matched with the sequence of an internal isolate (Hki8) from Callyspongia sp.

According to Bray-Curtis similarity matrices, based on the presence (indicated by 1 ) or absence (indicated by 0 ) of a given $\mathrm{T}-\mathrm{RF}$, the bacterial communities were divided into several distinct groups (Fig. 1). In particular, both the exterior and interior bacterial communities associated with both species of Callyspongia were different from bacterial communities found on reference substrata. Bacterial communities obtained from the exterior and interior surfaces of sponges Callyspongia sp. and C. plicifera were different from each other and formed separate clusters in the dendrogram (Fig. 1). Bacterial communities from adjacent substrata collected in Hong Kong were highly variable in bacterial composition, as indicated by a low similarity between reference replicates.

\section{Chemical profile of crude extracts from Callypongia spp.}

The chemical profiles of crude extracts from Callyspongia spp. from the Bahamas and Hong Kong were

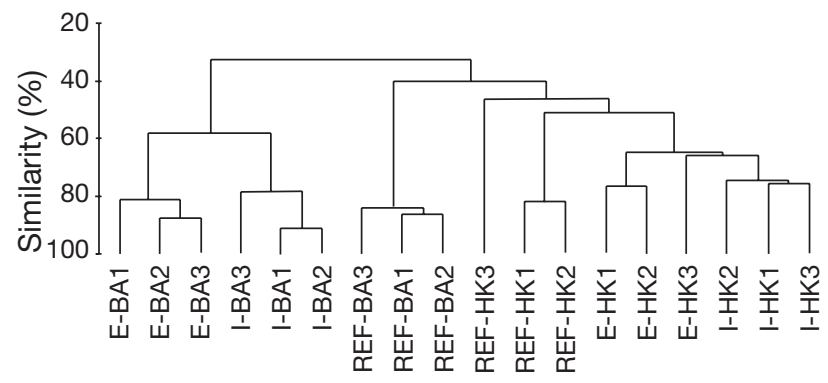

Fig. 1. Cluster analysis indicating similarities (\%) among bacterial communities obtained from exterior (E) and interior (I) tissue of sponges Callyspongia sp. (Hong Kong, HK) and Callyspongia plicifera (the Bahamas, BA) and reference sites (stones close to the sponge; REF-HK and REF-BA, correspondingly). Different replicates $(n=3)$ identified by corresponding numbers 
Table 1. Phylogenetic status of bacterial isolates from sponges Callyspongia plicifera (the Bahamas) and Callyspongia sp. (Hong Kong) and reference surfaces. 16S rRNA gene sequences of individual bacterial isolates were compared to nucleotide sequences in GenBank. The closest matching nucleotide sequence for each bacterial isolate is indicated by strain name, accession number and percent of sequence similarity

\begin{tabular}{|c|c|c|c|c|}
\hline Code & UST accession no. & Closest match in GenBank (accession no.) & Similarity (\%) & Location \\
\hline \multicolumn{5}{|c|}{ Proteobacteria, $\gamma$-Proteobacteria } \\
\hline Care321 & UST030701-192 & Balneatrix alpica Y17112 & 91 & Bahamas, exterior \\
\hline Care319 & UST030701-192 & Pseudomonas elongate AF500006 & 95 & Bahamas, exterior \\
\hline Care314 & UST030701-188 & Pseudoalteromonas porphyrae AY771715 & 97 & Bahamas, exterior \\
\hline Carr480 & UST030701-333 & Alteromonas marina AF529060 & 98 & Bahamas, substrata \\
\hline Carr507 & UST030701-362 & Alteromonas marina AF529060 & 99 & Bahamas, substrata \\
\hline Carr501 & UST030701-068 & Alteromonas marina AF529060 & 96 & Bahamas, substrata \\
\hline Carr495 & UST030701-348 & Pseudoalteromonas ruthenica AF316891 & 95 & Bahamas, substrata \\
\hline Hke13 & UST040911-013 & Vibrio harveyi AY750578 & 99 & Hong Kong, exterior \\
\hline Hke12 & UST040911-012 & Alteromonas macleodi Y18228 & 98 & Hong Kong, exterior \\
\hline Hke6 & UST040911-006 & Alteromonas macleodi Y18228 & 99 & Hong Kong, exterior \\
\hline Hke5 & UST040911-005 & Alteromonas marina AF529060 & 98 & Hong Kong, exterior \\
\hline Hke4 & UST040911-004 & Alteromonas macleodi subsp. fijiensi AJ414399 & 98 & Hong Kong, exterior \\
\hline Hke3 & UST040911-003 & Alteromonas marina AF529060 & 99 & Hong Kong, exterior \\
\hline Hke9 & UST040911-009 & Marinobacter aquaeolei AJ000726 & 99 & Hong Kong, exterior \\
\hline Hke2 & UST040911-002 & Psychrobacter sp. ANT9171 AY167289 & 98 & Hong Kong, exterior \\
\hline Hki20 & UST040911-035 & Vibrio tubiashi X74725 & 97 & Hong Kong, interior \\
\hline Hki18 & UST040911-033 & Vibrio natriegens X74714 & 99 & Hong Kong, interior \\
\hline Hki17 & UST040911-032 & Vibrio fischeri AY292941 & 99 & Hong Kong, interior \\
\hline Hki16 & UST040911-031 & Vibrio harveyi AY750578 & 99 & Hong Kong, interior \\
\hline Hki15 & UST040911-030 & Vibrio corallilyticus AJ440004 & 96 & Hong Kong, interior \\
\hline Hki13 & UST040911-028 & Vibrio harveyi AY750578 & 99 & Hong Kong, interior \\
\hline Hki12 & UST040911-027 & Vibrio harveyi AY750578 & 99 & Hong Kong, interior \\
\hline Hki10 & UST040911-025 & Vibrio corallilyticus AJ440004 & 99 & Hong Kong, interior \\
\hline Hki8 & UST040911-023 & Vibrio hollisae AJ514911 & 96 & Hong Kong, interior \\
\hline Hki6 & UST040911-021 & Vibrio corallilyticus AJ440004 & 99 & Hong Kong, interior \\
\hline Hki4 & UST040911-019 & Vibrio harveyi AY264925 & 97 & Hong Kong, interior \\
\hline Hki2 & UST040911-017 & Vibrio fischeri AY292941 & 99 & Hong Kong, interior \\
\hline Hkr11 & UST040911-046 & Alteromonas macleodii Y18228 & 99 & Hong Kong, substrata \\
\hline Hkr10 & UST040911-045 & Vibrio harveyi X74693 & 98 & Hong Kong, substrata \\
\hline Hkr9 & UST040911-044 & Alteromonas macleodii AMY18228 & 99 & Hong Kong, substrata \\
\hline Hkr8 & UST040911-043 & Alteromonas macleodii Y18228 & 97 & Hong Kong, substrata \\
\hline Hkr6 & UST040911-041 & Vibrio probioticus AJ345063 & 95 & Hong Kong, substrata \\
\hline Hkr3 & UST040911-038 & Vibrio aestuarianus AJ845014 & 94 & Hong Kong, substrata \\
\hline \multicolumn{5}{|c|}{$\alpha$-Proteobacteria } \\
\hline Cari307 & UST030701-185 & Pseudovibrio denitrificans AY486423 & 99 & Bahamas, interior \\
\hline Cari298 & UST030701-181 & Pseudovibrio denitrificans AY486423 & 99 & Bahamas, interior \\
\hline Carr515 & UST030701-031 & Pseudovibrio denitrificans AY486423 & 99 & Bahamas, substrata \\
\hline Carr504 & UST030701-359 & Erythrobacter flavus AF500005 & 98 & Bahamas, substrata \\
\hline Carr491 & UST030701-344 & Erythrobacter flavus strain SW-46 AF500004 & 99 & Bahamas, substrata \\
\hline Carr479 & UST030701-331 & Erythrobacter flavus strain SW-52 AF500005 & 100 & Bahamas, substrata \\
\hline Hki19 & UST040911-034 & Ruegeria atlantica D88527 & 96 & Hong Kong, interior \\
\hline Hki9 & UST040911-024 & Silicibacter lacuscaerulensis U77644 & 97 & Hong Kong, interior \\
\hline \multicolumn{5}{|c|}{ Firmicutes, Bacillales } \\
\hline Care308 & UST030701-186 & Bacillus hwajinpoensis AF541966 & 98 & Bahamas, exterior \\
\hline Cari299 & UST030701-182 & Bacillus megaterium AF142677 & 98 & Bahamas, interior \\
\hline Hke11 & UST040911-011 & Exiguobacterium sp. AY7444448 & 95 & Hong Kong, exterior \\
\hline Hke10 & UST040911-010 & Exiguobacterium marinum AY594266 & 97 & Hong Kong, exterior \\
\hline Hke 8 & UST040911-008 & Exiguobacterium gaetbuli AY594264 & 98 & Hong Kong, exterior \\
\hline Hke 7 & UST040911-007 & Planococcus citreus AF500008 & 98 & Hong Kong, exterior \\
\hline Hki7 & UST040911-022 & Bacillus sp. ROO40 AY188840 & 99 & Hong Kong, interior \\
\hline Hki3 & UST040911-018 & Bacillus megaterium AF142677 & 99 & Hong Kong, interior \\
\hline Hki1 & UST040911-016 & Bacillus cereus ZK CP000001 & 98 & Hong Kong, interior \\
\hline Hkr16 & UST040911-050 & Bacillus thuringiensis serovar konkukian AE017 & 1735599 & Hong Kong, substrata \\
\hline Hkr15 & UST040911-049 & Bacillus cereus ZK CP000001 & 99 & Hong Kong, substrata \\
\hline Hkr14 & UST040911-048 & Bacillus cereus ATCC 14579 AE017013 & 97 & Hong Kong, substrata \\
\hline Hkr7 & UST040911-042 & Exiguobacterium marinum AY594266 & 98 & Hong Kong, substrata \\
\hline Hkr4 & UST040911-039 & Bacillus megaterium AJ717381 & 97 & Hong Kong, substrata \\
\hline Hkr2 & UST040911-037 & Bacillus cereus ATCC 14579 AE17013 & 99 & Hong Kong, substrata \\
\hline Hkr1 & UST040911-036 & Bacillus cereus ZK CP000001 & 99 & Hong Kong, substrata \\
\hline \multicolumn{5}{|c|}{ Bacteroides, Schingobacteria } \\
\hline Carr492 & UST030701-345 & Microscilla furvescens AB078079 & 97 & Bahamas, substrata \\
\hline \multicolumn{5}{|c|}{ Actinobacteria, Actinobacteridae } \\
\hline Hki14 & UST040911-029 & Micrococcus luteus AJ717367 & 99 & Hong Kong, interior \\
\hline Hki11 & UST040911-026 & Micrococcus sp. Ellin149 AF408991 & 99 & Hong Kong, interior \\
\hline Hki5 & UST040911-020 & Micrococcus luteus AJ717369 & 98 & Hong Kong, interior \\
\hline
\end{tabular}


Table 2. T-RFLP profiles of bacterial communities obtained from exterior (E) and interior (I) tissues of sponges Callyspongia sp. (Hong Kong, HK) and C. plicifera (the Bahamas, BA) and reference substratum from the near vicinity (REF-HK and REF-BA, correspondingly). The presence and fragment sizes (bp) of individual T-RFs are denoted as follows: $\mathrm{X}^{\mathrm{a}}=$ present in 3 out of 3 replicates; $\mathrm{X}^{\mathrm{b}}=$ present in 2 out of 3 replicates (presence in 1 out of 3 replicates is omitted). Blank cell = absence of particular T-RF in a given biofilm

\begin{tabular}{|c|c|c|c|c|c|c|c|c|c|c|c|c|c|}
\hline T-RF (bp) & E-BA & I-BA & REF-BA & E-HK & I-HK & REF-HK & T-RF (bp) & E-BA & I-BA & REF-BA & E-HK & I-HK & REF-HK \\
\hline 40 & & & $\mathrm{X}^{\mathrm{a}}$ & & & & 208 & & & & $\mathrm{X}^{\mathrm{a}}$ & $\mathrm{X}^{\mathrm{a}}$ & $\mathrm{X}^{\mathrm{a}}$ \\
\hline 41 & $\mathrm{X}^{\mathrm{b}}$ & $\mathrm{X}^{\mathrm{a}}$ & & $\mathrm{X}^{\mathrm{a}}$ & $\mathrm{X}^{\mathrm{a}}$ & & 209 & & $\mathrm{X}^{\mathrm{b}}$ & & & $X^{a}$ & $\mathrm{X}^{\mathrm{a}}$ \\
\hline 42 & & & & & $\mathrm{X}^{\mathrm{b}}$ & & 215 & & & $\mathrm{X}^{\mathrm{a}}$ & & & \\
\hline 44 & & & & & $\mathrm{X}^{\mathrm{a}}$ & $\mathrm{X}^{\mathrm{a}}$ & 219 & & & & $\mathrm{X}^{\mathrm{a}}$ & & \\
\hline 45 & & & & $\mathrm{X}^{\mathrm{a}}$ & & $\mathrm{X}^{\mathrm{b}}$ & 221 & & & & $\mathrm{X}^{\mathrm{a}}$ & & \\
\hline 46 & & & & & & $\mathrm{X}^{\mathrm{b}}$ & 222 & & & & & $\mathrm{X}^{\mathrm{a}}$ & \\
\hline 47 & & & & $\mathrm{X}^{\mathrm{b}}$ & $X^{a}$ & $\mathrm{X}^{\mathrm{b}}$ & 242 & & & & & $\mathrm{X}^{\mathrm{a}}$ & \\
\hline 48 & & & & $\mathrm{X}^{\mathrm{b}}$ & & $\mathrm{X}^{\mathrm{b}}$ & 246 & $\mathrm{X}^{\mathrm{a}}$ & $\mathrm{X}^{\mathrm{a}}$ & $\mathrm{X}^{\mathrm{b}}$ & $\mathrm{X}^{\mathrm{a}}$ & $\mathrm{X}^{\mathrm{b}}$ & $\mathrm{X}^{\mathrm{b}}$ \\
\hline 69 & & & & $\mathrm{X}^{\mathrm{a}}$ & $\mathrm{X}^{\mathrm{b}}$ & & 247 & & & $\mathrm{X}^{\mathrm{a}}$ & & & \\
\hline 71 & & & $\mathrm{X}^{\mathrm{a}}$ & $\mathrm{X}^{\mathrm{b}}$ & & $X^{a}$ & 248 & & & & $\mathrm{X}^{\mathrm{a}}$ & $\mathrm{X}^{\mathrm{a}}$ & $\mathrm{X}^{\mathrm{b}}$ \\
\hline 73 & & & $\mathrm{X}^{\mathrm{b}}$ & & & & 298 & & $X^{a}$ & & & $\mathrm{X}^{\mathrm{b}}$ & \\
\hline 74 & & & $\mathrm{X}^{\mathrm{a}}$ & $\mathrm{X}^{\mathrm{b}}$ & & & 299 & & $\mathrm{X}^{\mathrm{b}}$ & $\mathrm{X}^{\mathrm{a}}$ & $\mathrm{X}^{\mathrm{a}}$ & $\mathrm{X}^{\mathrm{a}}$ & $\mathrm{X}^{\mathrm{a}}$ \\
\hline 75 & & & $\mathrm{X}^{\mathrm{a}}$ & $\mathrm{X}^{\mathrm{a}}$ & $\mathrm{X}^{\mathrm{a}}$ & & 300 & & $\mathrm{X}^{\mathrm{a}}$ & $\mathrm{X}^{\mathrm{a}}$ & $\mathrm{X}^{\mathrm{a}}$ & & \\
\hline 77 & & & & & & $X^{a}$ & 301 & & & $\mathrm{X}^{\mathrm{a}}$ & & & $\mathrm{X}^{\mathrm{a}}$ \\
\hline 79 & & & & & & $\mathrm{X}^{\mathrm{b}}$ & 302 & & & $\mathrm{X}^{\mathrm{a}}$ & $\mathrm{X}^{\mathrm{a}}$ & $\mathrm{X}^{\mathrm{a}}$ & $\mathrm{X}^{\mathrm{a}}$ \\
\hline 85 & & $\mathrm{X}^{\mathrm{a}}$ & & & & & 307 & $\mathrm{X}^{\mathrm{a}}$ & $X^{a}$ & & & & \\
\hline 89 & & & $\mathrm{X}^{\mathrm{b}}$ & $\mathrm{X}^{\mathrm{a}}$ & $\mathrm{X}^{\mathrm{b}}$ & & 309 & $\mathrm{X}^{\mathrm{b}}$ & & & $\mathrm{X}^{\mathrm{a}}$ & $\mathrm{X}^{\mathrm{a}}$ & \\
\hline 91 & & & & & & $\mathrm{X}^{\mathrm{a}}$ & 310 & $\mathrm{X}^{\mathrm{a}}$ & $\mathrm{X}^{\mathrm{a}}$ & & $\mathrm{X}^{\mathrm{b}}$ & $\mathrm{X}^{\mathrm{a}}$ & \\
\hline 93 & & & & $\mathrm{X}^{\mathrm{b}}$ & $\mathrm{X}^{\mathrm{b}}$ & & 312 & & $\mathrm{X}^{\mathrm{b}}$ & $\mathrm{X}^{\mathrm{a}}$ & & & $\mathrm{X}^{\mathrm{a}}$ \\
\hline 100 & & & & & $\mathrm{X}^{\mathrm{a}}$ & & 313 & & & $\mathrm{X}^{\mathrm{a}}$ & $\mathrm{X}^{\mathrm{b}}$ & & $\mathrm{X}^{\mathrm{a}}$ \\
\hline 109 & & $X^{a}$ & & & & & 314 & & & & & $\mathrm{X}^{\mathrm{b}}$ & $\mathrm{X}^{\mathrm{a}}$ \\
\hline 119 & & $\mathrm{X}^{\mathrm{a}}$ & & $\mathrm{X}^{\mathrm{b}}$ & $\mathrm{X}^{\mathrm{b}}$ & & 315 & & & & $\mathrm{X}^{\mathrm{a}}$ & & \\
\hline 121 & & & & & $\mathrm{X}^{\mathrm{a}}$ & & 364 & & $\mathrm{X}^{\mathrm{a}}$ & & & & \\
\hline 122 & & & & $\mathrm{X}^{\mathrm{b}}$ & $\mathrm{X}^{\mathrm{a}}$ & & 369 & $\mathrm{X}^{\mathrm{b}}$ & $\mathrm{X}^{\mathrm{a}}$ & & $\mathrm{X}^{\mathrm{b}}$ & $\mathrm{X}^{\mathrm{a}}$ & \\
\hline 123 & & $X^{a}$ & & & & & 370 & & $\mathrm{X}^{\mathrm{a}}$ & & $\mathrm{X}^{\mathrm{a}}$ & $\mathrm{X}^{\mathrm{a}}$ & $\mathrm{X}^{\mathrm{a}}$ \\
\hline 126 & & & & $\mathrm{X}^{\mathrm{b}}$ & & $\mathrm{X}^{\mathrm{b}}$ & 371 & & & & $\mathrm{X}^{\mathrm{a}}$ & $\mathrm{X}^{\mathrm{a}}$ & $\mathrm{X}^{\mathrm{b}}$ \\
\hline 127 & & & & $\mathrm{X}^{\mathrm{a}}$ & $\mathrm{X}^{\mathrm{a}}$ & & 373 & & & $\mathrm{X}^{\mathrm{a}}$ & & & \\
\hline 130 & & & & $\mathrm{X}^{\mathrm{a}}$ & $\mathrm{X}^{\mathrm{b}}$ & & 374 & $\mathrm{X}^{\mathrm{a}}$ & & & & & $\mathrm{X}^{\mathrm{b}}$ \\
\hline 147,150 & & & & & $\mathrm{X}^{\mathrm{b}}$ & & 375 & $\mathrm{X}^{\mathrm{a}}$ & $\mathrm{X}^{\mathrm{a}}$ & & & & $\mathrm{X}^{\mathrm{a}}$ \\
\hline 176 & $\mathrm{X}^{\mathrm{a}}$ & $\mathrm{X}^{\mathrm{a}}$ & & & & & 376 & & & & $\mathrm{X}^{\mathrm{a}}$ & $\mathrm{X}^{\mathrm{a}}$ & $\mathrm{X}^{\mathrm{b}}$ \\
\hline 177 & & $X^{a}$ & & $\mathrm{X}^{\mathrm{b}}$ & & & 377 & & & & & $\mathrm{X}^{\mathrm{a}}$ & \\
\hline 179 & & & & $X^{a}$ & $X^{a}$ & $\mathrm{X}^{\mathrm{b}}$ & 400 & & $\mathrm{X}^{\mathrm{b}}$ & & & & \\
\hline 180 & & & $\mathrm{X}^{\mathrm{a}}$ & $\mathrm{X}^{\mathrm{a}}$ & & $\mathrm{X}^{\mathrm{a}}$ & 416 & $\mathrm{X}^{\mathrm{b}}$ & & & & & \\
\hline 182 & & & $\mathrm{X}^{\mathrm{a}}$ & $\mathrm{X}^{\mathrm{a}}$ & $\mathrm{X}^{\mathrm{a}}$ & $\mathrm{X}^{\mathrm{a}}$ & 417 & $\mathrm{X}^{\mathrm{b}}$ & & & & & \\
\hline 184 & & & & $\mathrm{X}^{\mathrm{b}}$ & $\mathrm{X}^{\mathrm{a}}$ & & 419 & $\mathrm{X}^{\mathrm{a}}$ & $\mathrm{X}^{\mathrm{a}}$ & & $\mathrm{X}^{\mathrm{b}}$ & $\mathrm{X}^{\mathrm{a}}$ & \\
\hline 199 & & & & $\mathrm{X}^{\mathrm{a}}$ & $\mathrm{X}^{\mathrm{a}}$ & & 422 & $\mathrm{X}^{\mathrm{a}}$ & $\mathrm{X}^{\mathrm{b}}$ & $\mathrm{X}^{\mathrm{a}}$ & $\mathrm{X}^{\mathrm{b}}$ & $\mathrm{X}^{\mathrm{a}}$ & \\
\hline 202 & & $\mathrm{X}^{\mathrm{a}}$ & & $\mathrm{X}^{\mathrm{b}}$ & & & 423 & & & & $\mathrm{X}^{\mathrm{a}}$ & $\mathrm{X}^{\mathrm{b}}$ & $\mathrm{X}^{\mathrm{b}}$ \\
\hline 204 & & & & & $\mathrm{X}^{\mathrm{a}}$ & $\mathrm{X}^{\mathrm{a}}$ & 424 & & & & $\mathrm{X}^{\mathrm{b}}$ & & \\
\hline 205 & & & & $\mathrm{X}^{\mathrm{a}}$ & & $\mathrm{X}^{\mathrm{a}}$ & 431 & & & & & & $\mathrm{X}^{\mathrm{b}}$ \\
\hline \multirow[t]{2}{*}{207} & & & & & & $\mathrm{X}^{\mathrm{b}}$ & 455 & & & & & & $\mathrm{X}^{\mathrm{a}}$ \\
\hline & & & & & & & Total number & 13 & 23 & 19 & 43 & 40 & 35 \\
\hline
\end{tabular}

very similar compared with extracts of Halichondria spp. from the same locations (Fig. 2, Table 3). More than $60 \%$ of compounds from the congeneric sponges Callyspongia sp. and C. plicifera were similar, while the percentage similarity between extracts of Halichondria sp. and $H$. melanodocia was noticeably lower. Some peaks (i.e. peak with retention time $14.9 \mathrm{~min}$ ) were present in all sponges, indicating that Demospongiae from different phylogenetic groups may have similar secondary metabolites (Table 3). Some metabolites (i.e. peaks with retention times of 6.5, 13.1 and $14.3 \mathrm{~min}$ ) were specific only to congeneric species of sponges but there were also specific secondary metabolites that were present only in particular species of sponges (i.e. peaks with retention times of 3.1, 5.1, 5.6 and $16.0 \mathrm{~min})$.

\section{Antibacterial assay}

Extracts of both Callyspongia sp. and C. plicifera inhibited the growth of bacterial isolates from the Bahamas reference site at TL and 10x TL concentrations (Fig. 3A). At TL concentration, the crude extracts 
Table 3. Gas chromatography-mass spectrometry (GC-MS) analysis of dichloromethane extracts of Callyspongia sp. and Halichondria sp. from Hong Kong, and C. plicifera and H. melanodocia from the Bahamas. X = presence of peaks; blank cells $=$ absence of peaks. Peaks were identified by NIST GC-MS library; compounds with a probability $<20 \%$ to closest match with library marked as unknown

\begin{tabular}{|c|c|c|c|c|c|c|}
\hline $\begin{array}{l}\text { Peak } \\
\text { retention } \\
\text { time (min) }\end{array}$ & $\begin{array}{l}\text { Callyspongia } \\
\text { sp. }\end{array}$ & Extract & $\begin{array}{l}\text { chondria } \\
\text { sp. }\end{array}$ & $\begin{array}{c}H . \\
\text { melanodocia }\end{array}$ & Close match to the library & Probability \\
\hline 3.1 & & & $\mathrm{X}$ & & Unknown & $<20$ \\
\hline 3.2 & & & $\mathrm{X}$ & & Disiloxane, 1,3-bis(chloromethyl)-1,1,3,3-tetramethyl & 55 \\
\hline 3.4 & & & $\mathrm{X}$ & & Unknown & $<20$ \\
\hline 3.5 & & & $\mathrm{X}$ & & Propanoic acid, 3-(trimethylsilyl), ethyl ester & 44 \\
\hline 5.1 & $\mathrm{X}$ & & & & 1,3,3-trimethoxybutane & 75 \\
\hline 5.4 & & & $\mathrm{X}$ & & Pyridine, 3-trimethylsiloxy- & 74 \\
\hline 5.6 & $\mathrm{X}$ & & & & Pyridine, 2, 4,6-trimethyl- & 48 \\
\hline 5.6 & & & & $\mathrm{X}$ & Silanol, trimethyl carobonate $(2: 1)$ & 61 \\
\hline 5.8 & & & $\mathrm{X}$ & $\mathrm{X}$ & $\begin{array}{l}\text { Propanoic acid, 2-[(trimethylsilyl)oxy-], } \\
\text { trimethylsilyl ester }\end{array}$ & 33 \\
\hline 6.2 & & & $\mathrm{X}$ & & $\begin{array}{l}\text { Methyl 2-[2-(4-chlorophenyl)-5-methyl- } \\
\text { 1H]imidazol-1-yl]dithiobenzoate }\end{array}$ & 34 \\
\hline 6.3 & & & & $\mathrm{X}$ & $\begin{array}{l}\text { Pentaneodioic acid., 2-[(trimethylsilyl)oxy]-, } \\
\text { dimethyl ester }\end{array}$ & 53 \\
\hline 6.5 & $\mathrm{X}$ & $\mathrm{X}$ & & & Unknown & $<20$ \\
\hline 7.2 & & & & $\mathrm{X}$ & $\begin{array}{l}\text { Arabino-hexos-2-ulose, 3, 4, 5, 6-tetrakis-O- } \\
\text { (trimethylsilyl)-, bis(dimethyl acetal) }\end{array}$ & 73 \\
\hline 7.3 & $\mathrm{X}$ & & & & 2-ethyl-6-isopropyl pyridine & 62 \\
\hline 7.5 & & & & $\mathrm{X}$ & Benzoic acid trimethylsylyl ester & 42 \\
\hline 7.6 & & & $\mathrm{X}$ & & Pentasiloxane dodecamethyl- & 78 \\
\hline 8.1 & $\mathrm{X}$ & $\mathrm{X}$ & & & Silane, cyclohexyldimethoxymethyl- & 92 \\
\hline 8.6 & $\mathrm{X}$ & & & & Pyridine, 2,4,6-trimethyl- & 39 \\
\hline 8.8 & $\mathrm{X}$ & & & & Pentasiloxane dodecamethyl- & 73 \\
\hline 8.9 & & & $\mathrm{X}$ & & Trimethylsilyl ether of glycerol & 75 \\
\hline 9.2 & $\mathrm{X}$ & $\mathrm{X}$ & & $\mathrm{X}$ & $\begin{array}{l}\text { Alpha-D-galactopyranoside, methyl 2,3-bis-O- } \\
\text { (trimethylsilyl)- cyclic methylboronate }\end{array}$ & 22 \\
\hline 9.4 & $\mathrm{X}$ & $\mathrm{X}$ & & & Unknown & $<20$ \\
\hline 9.7 & $\mathrm{X}$ & $\mathrm{X}$ & & & Hexyl octyl ether & 22 \\
\hline 10.7 & & & $\mathrm{X}$ & & Aminomalonic acid, tris(trimethylsilyl)- & 94 \\
\hline 10.8 & $\mathrm{X}$ & & & & Hexasiloxane tetradecamethyl & 96 \\
\hline 11.2 & & & & $\mathrm{X}$ & Creatinine enol tri-TMS & 90 \\
\hline 11.6 & & & $\mathrm{X}$ & & $\begin{array}{l}\text { n-octanoic acid, 2-[(trimethyl)amino]-, } \\
\text { trimethylsilyl ester }\end{array}$ & 25 \\
\hline 12.2 & $\mathrm{X}$ & $\mathrm{X}$ & & $\mathrm{X}$ & 3,5-di-tert-butyl-4-trimethylsiloxytoluene & 84 \\
\hline 12.5 & $\mathrm{X}$ & $\mathrm{X}$ & & & Phenol 2,4,bis (1,1-dimethyl)- & 40 \\
\hline 12.6 & $\mathrm{X}$ & & & & Heptasiloxane hexadecamethyl & 95 \\
\hline 12.8 & & & $\mathrm{X}$ & & $\begin{array}{l}\text { Myo-inositol, 5-deoxy-1,2,3,4,6-pentakis-O- } \\
\text { (trimethylsilyl)- }\end{array}$ & 24 \\
\hline 13.1 & & & $\mathrm{X}$ & $\mathrm{X}$ & Cyclononasiloxane, octadecamethyl & 83 \\
\hline 13.4 & & & $\mathrm{X}$ & & Unknown & $<20$ \\
\hline 13.8 & & & $\mathrm{X}$ & & Unknown & $<20$ \\
\hline 13.9 & & & & $\mathrm{X}$ & Hexadecanoic acid, trimethylsilyl ester & 82 \\
\hline 14.3 & $\mathrm{X}$ & $\mathrm{X}$ & & & 1-octanol 2 butyl & 22 \\
\hline 14.6 & $\mathrm{X}$ & & & & Methyl 12-methyl-tridecanoate & 88 \\
\hline 14.9 & $\mathrm{X}$ & $\mathrm{X}$ & $\mathrm{X}$ & $\mathrm{X}$ & Arachidonic acid & 25 \\
\hline 15.0 & $\mathrm{X}$ & & & & Methyl 12-methyl-tridecanoate & 43 \\
\hline 15.1 & & & $\mathrm{X}$ & $\mathrm{X}$ & Palmitelacidic acid, trimethylsilyl ester & 88 \\
\hline 15.2 & & & & $\mathrm{X}$ & Hexadecanoic acid, trimethylsilyl ester & 75 \\
\hline 15.4 & & & $\mathrm{X}$ & & Unknown & $<20$ \\
\hline 15.5 & & & & $\mathrm{X}$ & Unknown & $<20$ \\
\hline 15.8 & & & & $\mathrm{X}$ & Cyclononasiloxane, octadecamethyl & 72 \\
\hline 15.9 & $\mathrm{X}$ & & & & Unknown & $<20$ \\
\hline 16.0 & & $\mathrm{X}$ & & & Methyl palmitate & 80 \\
\hline 16.1 & $\mathrm{X}$ & $\mathrm{X}$ & & & 11-hexadecenoic acid methyl ester & 46 \\
\hline 16.2 & $\mathrm{X}$ & & & & $\begin{array}{l}\text { 7,9-di-tert-butyl-1-oxaspiro }(4,5) \text { deca- } 6 \text {, } \\
\text { 9-diene-2,8-dione }\end{array}$ & 57 \\
\hline 16.3 & $\mathrm{X}$ & $\mathrm{X}$ & & & 3-acridinol, 9-phenyl & 43 \\
\hline 16.6 & $\mathrm{X}$ & $\mathrm{X}$ & & & Unknown & $<20$ \\
\hline
\end{tabular}


Table 3 (continued)

\begin{tabular}{|c|c|c|c|c|c|c|}
\hline $\begin{array}{l}\text { Peak } \\
\text { retention } \\
\text { time (min) }\end{array}$ & $\begin{array}{l}\text { Callyspongia } \\
\text { sp. }\end{array}$ & $\begin{array}{c}C . \\
\text { plicifera }\end{array}$ & $\begin{array}{l}\text { ichondria } \\
\text { sp. }\end{array}$ & $\begin{array}{c}H . \\
\text { melanodocia }\end{array}$ & Close match to the library & $\begin{array}{c}\text { Probability } \\
\%\end{array}$ \\
\hline 16.9 & $\mathrm{X}$ & $\mathrm{X}$ & & & Hexadecanoic acid 15 methyl ester & 38 \\
\hline 17.0 & & $\mathrm{X}$ & $\mathrm{X}$ & & 5-hexadecenoic acid 2-methoxy methyl ester & 23 \\
\hline 17.1 & & & $\mathrm{X}$ & $\mathrm{X}$ & 9,12-octadecanoic acid (Z,Z)-, trimethylsilyl ester & 26 \\
\hline 17.2 & $\mathrm{X}$ & $\mathrm{X}$ & $\mathrm{X}$ & & Octadecanoic acid eicosyl ester & 21 \\
\hline 17.3 & & & & $\mathrm{X}$ & 11-trans-octadecenoic acid, trimethylsilyl ester & 28 \\
\hline 17.5 & & & & $\mathrm{X}$ & Cyclodecasiloxane, eicosamethyl- & 66 \\
\hline 17.7 & $\mathrm{X}$ & $\mathrm{X}$ & & & 13-octadecenoic acid methyl ester Z & 23 \\
\hline 17.8 & $\mathrm{X}$ & & $\mathrm{X}$ & & 1-dotriacontanol & 22 \\
\hline 17.9 & & $\mathrm{X}$ & & & Methyl octadecanoate & 68 \\
\hline 18.2 & $\mathrm{X}$ & $\mathrm{X}$ & & & 2-hexadecenoic acid 2,3,-dimethyl methyl ester E & 24 \\
\hline 18.3 & & & $\mathrm{X}$ & & Unknown & $<20$ \\
\hline 18.4 & & & $\mathrm{X}$ & & $\begin{array}{l}\text { Cephalotaxine, 11-(acetyloxy)-, acetate (ester), } \\
\text { (11. Alpha) }\end{array}$ & 25 \\
\hline 18.7 & & $\mathrm{X}$ & & $\mathrm{X}$ & Octadecanoic acid 14-methyl methyl ester & 29 \\
\hline 18.9 & & & & $\mathrm{X}$ & 1-monolinoleoylglycerol trimethylsilyl ether & 29 \\
\hline 19.0 & & $\mathrm{X}$ & & & Tetrahydriaraucarolone & 55 \\
\hline 19.1 & & $\mathrm{X}$ & & & $\begin{array}{l}\text { 3-oxatricyclo[0.8.0.0(7,16)]triconta-1(22), } \\
\quad 7(16), 9,13,23,29 \text {-hexaene }\end{array}$ & 38 \\
\hline 19.2 & & $\mathrm{X}$ & & & 14-oxononadec-10-enoic acid methyl ester & 22 \\
\hline 19.3 & $\mathrm{X}$ & $\mathrm{X}$ & & & Nonadecanoic acid 10-methyl methyl ester & 46 \\
\hline 19.5 & & $\mathrm{X}$ & & & Unknown & $<20$ \\
\hline 19.9 & $\mathrm{X}$ & $\mathrm{X}$ & & & Heneicosanoic acid methyl ester & 96 \\
\hline 20.1 & & & & $\mathrm{X}$ & Cyclodecasiloxane, eicosamethyl- & 57 \\
\hline 20.2 & $\mathrm{X}$ & & $\mathrm{X}$ & & Unknown & $<20$ \\
\hline 20.3 & $\mathrm{X}$ & & & & Unknown & $<20$ \\
\hline 20.4 & $\mathrm{X}$ & & $\mathrm{X}$ & & Unknown & $<20$ \\
\hline 20.5 & $\mathrm{X}$ & & & & \multicolumn{2}{|c|}{ Tricycle[20.8.0.0(7,16)] triacontane, 1(22), 7(16)-diepoxy 28} \\
\hline 20.7 & $\mathrm{X}$ & $\mathrm{X}$ & & & Unknown & $<20$ \\
\hline 20.8 & $\mathrm{X}$ & $\mathrm{X}$ & & & Unknown & $<20$ \\
\hline 21.4 & & $\mathrm{X}$ & & & 13-octadecenal (Z) & 24 \\
\hline 21.6 & & $\mathrm{X}$ & & & Docosahexaenooic acid 1,2,3,-propanetriyl ester & 22 \\
\hline 21.8 & & $\mathrm{X}$ & & $\mathrm{X}$ & $\mathrm{E}, \mathrm{E}, \mathrm{Z}-1,3,12-$ Nonadecatriene-5,14-diol & 24 \\
\hline 21.9 & & $\mathrm{X}$ & & & 15-tetracosenoic acid, methyl ester (Z) & 64 \\
\hline 22.0 & $\mathrm{X}$ & $\mathrm{X}$ & & & Tetracosanoic acid & 89 \\
\hline 22.3 & $\mathrm{X}$ & & & & $\begin{array}{l}\text { Benzenedodecanoic acid, } \\
\text { 3-methoxy-2-(methoxycarbonyl)-methyl ester }\end{array}$ & 24 \\
\hline 22.4 & & & $\mathrm{X}$ & & Unknown & $<20$ \\
\hline 22.5 & $\mathrm{X}$ & $\mathrm{X}$ & & & Squalene & 28 \\
\hline 22.6 & $\mathrm{X}$ & & & & Pentacosanoic acid methyl ester & 90 \\
\hline 22.9 & $\mathrm{X}$ & $\mathrm{X}$ & & & Unknown & $<20$ \\
\hline 23.2 & $\mathrm{X}$ & $\mathrm{X}$ & & & Hexacosanoic acid methyl ester & 55 \\
\hline 23.3 & & $\mathrm{X}$ & & & Unknown & $<20$ \\
\hline 23.5 & & $\mathrm{X}$ & & & 26,27-dinorergost-5-ene-3,24-diol, (3.beta) & 39 \\
\hline 24.2 & $\mathrm{X}$ & $\mathrm{X}$ & & & 5,14,23,-octadecatrien-14,15-diol & 22 \\
\hline 24.4 & $\mathrm{X}$ & $\mathrm{X}$ & & & Cholesta-5, 22-dien-3-ol,(3beta) & 21 \\
\hline 24.7 & $X$ & $\mathrm{X}$ & & & $\begin{array}{l}\text { 17-(1,5-dimethylhexyl)-10,13-dimethyl- } \\
2,3,4,7,8,9,10,11,12,13,14,15,16,17 \text {-tetra }\end{array}$ & 61 \\
\hline 25.0 & $\mathrm{X}$ & $\mathrm{X}$ & & & Unknown & $<20$ \\
\hline 25.3 & & & & $\mathrm{X}$ & Unknown & $<20$ \\
\hline 25.4 & $\mathrm{X}$ & $\mathrm{X}$ & & & 26,26-dimethyl-5,24(28)-ergostadien-3.beta-ol & 25 \\
\hline 25.5 & $\mathrm{X}$ & $\mathrm{X}$ & & & Campesterol & 23 \\
\hline 25.7 & $\mathrm{X}$ & $\mathrm{X}$ & & & Stigmasterol & 62 \\
\hline 26.2 & & $\mathrm{X}$ & & & Beta-sitosterol & 42 \\
\hline 26.4 & $\mathrm{X}$ & $\mathrm{X}$ & & & Sigmasta-5, 24(28)-dien-3-ol, (3beta) & 42 \\
\hline 26.5 & & & $\mathrm{X}$ & & Pregn-5-ene-3,11,20-trione & 27 \\
\hline 27.0 & $\mathrm{X}$ & $\mathrm{X}$ & & & 26,26 -dimethyl-5,24(28)-ergostadien-3.beta-ol & 30 \\
\hline 27.6 & & & & $\mathrm{X}$ & Unknown & $<20$ \\
\hline 28.6 & & $\mathrm{X}$ & & & Lycoxanthin & 42 \\
\hline 29.0 & & $\mathrm{X}$ & & & $\begin{array}{l}\text { Benzenepropanoic acid, } \\
\text { 3,5-bis(1,1-dimethylethyl)-4-hydroxy-octadecyl }\end{array}$ & ester 64 \\
\hline
\end{tabular}




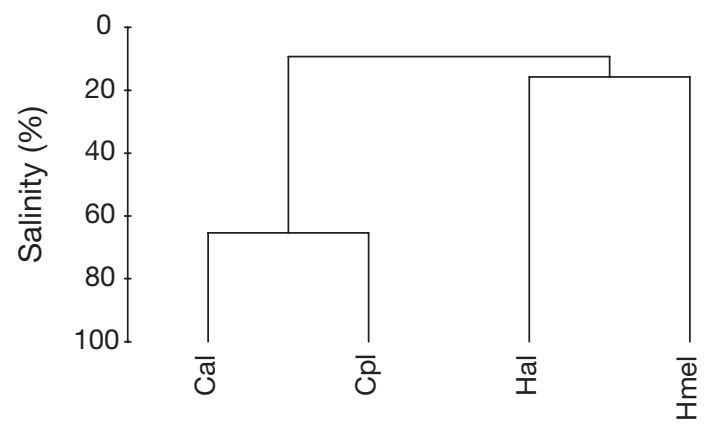

Fig. 2. Cluster analysis indicating similarities (\%) among crude extracts of sponges Callyspongia sp. (Hong Kong, Cal), C. plicifera (the Bahamas, Cpl), Halichondria sp. (Hong Kong, Hal) and H. melanodocia (the Bahamas, Hmel)

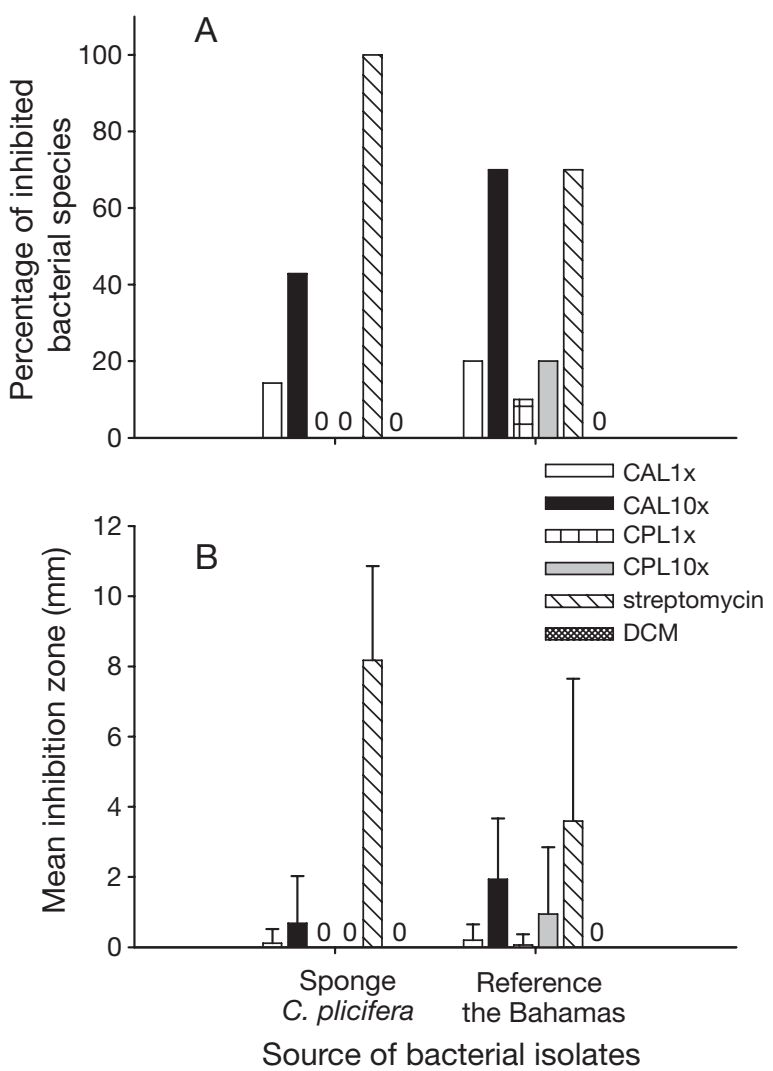

Fig. 3. Inhibition of growth of bacterial isolates from sponge Callyspongia plicifera and reference substrata from the Bahamas. In total, 9 isolates from reference substrata and strains from C. plicifera were tested. (A) Percentage of bacterial isolates inhibited by crude extracts of Callyspongia sp. (CAL) and C. plicifera (CPL) at tissue level (TL; $1 \times$ ) and 10 times TL $(10 \times)$ concentrations. (B) Mean \pm SD of inhibition zones $(\mathrm{mm})$ in disc diffusion bioassays with crude extracts of Callyspongia sp. and C. plicifera at TL $(1 \times)$ and 10 times TL $(10 \times)$ concentrations. Streptomycin $40 \mu \mathrm{g} \mathrm{disc}{ }^{-1}$ and dichloromethane (DCM; $20 \mu \mathrm{g} \mathrm{disc}^{-1}$ ) used as controls. Due to low numbers, bacterial isolates from $C$. plicifera were combined into 1 sample; $0=$ no inhibition of growth of a particular group of bacterial isolates had much less of an antibiotic effect on reference bacteria from the Bahamas than the streptomycin control, whereas the crude extracts of Callyspongia sp. at 10x TL concentration level were as inhibitory as the streptomycin control for reference bacteria (Fig. 3A,B). Extracts of C. plicifera did not inhibit the growth of isolates from this sponge, while extracts of Callyspongia sp. had little inhibitory effect on the growth of these bacteria. The DCM control did not affect bacterial growth (Figs. 3 \& 4).

At TL concentration and 10× TL concentration, the extracts of both Callyspongia sp. and C. plicifera effectively inhibited the growth of reference bacteria from Hong Kong, while the strains associated with the interior surface of Callyspongia sp. were less sensitive to sponge extracts (Fig. 4). The extracts of Callyspongia sp. at TL concentration did not affect the growth of bacteria from the interior of this sponge. In contrast,

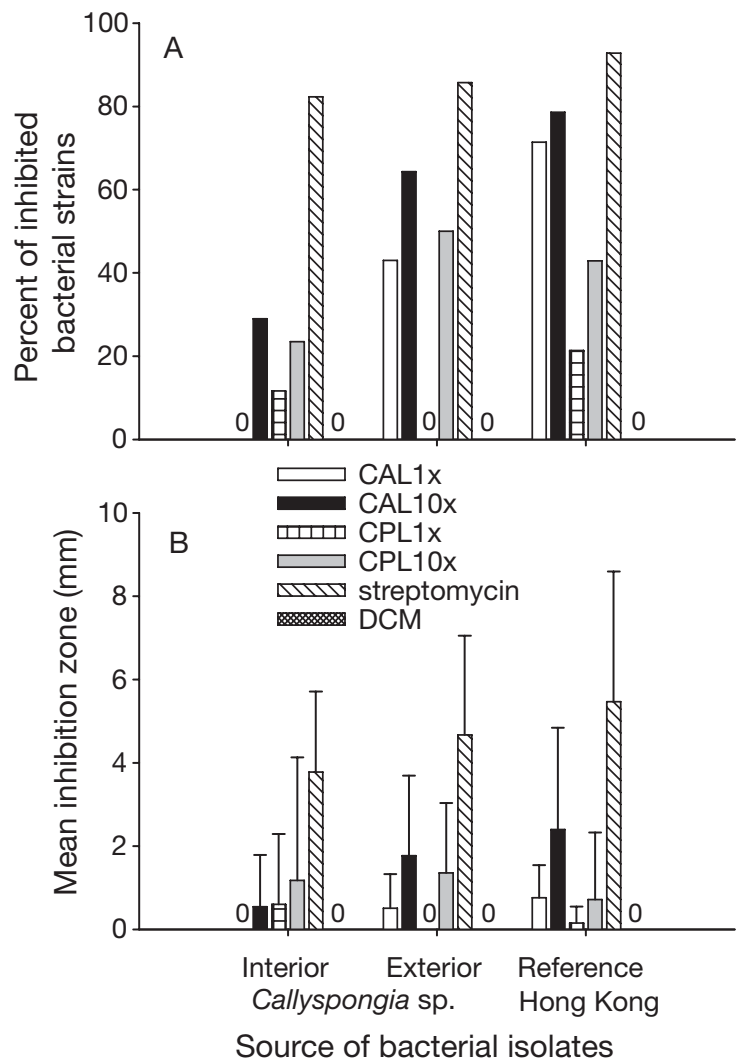

Fig. 4. Inhibition of growth of bacterial isolates from sponge Callyspongia sp. and reference substrata from Hong Kong. (A) Percentage of bacterial isolates inhibited by crude extracts of Callyspongia sp. (CAL) and C. plicifera (CPL) at TL $(1 \times)$ and 10 times TL (10×) concentrations. (B) Mean \pm SD of inhibition zones $(\mathrm{mm})$ in a disc diffusion bioassay with crude extracts of Callyspongia sp. and C. plicifera at TL (1×) and 10 times TL (10×) concentrations. Streptomycin at $\mu \mathrm{g} \mathrm{disc}{ }^{-1}$ and DCM $\left(20 \mu \mathrm{g} \mathrm{disc}{ }^{-1}\right)$ used as controls; $0=$ no inhibition of growth of a particular group of bacterial isolates 
the extracts of $C$. plicifera inhibited the growth of bacteria from both internal and reference substrata at TL concentration but did not affect the growth of external isolates. The least amount of inhibition was observed for sponge extracts at TL concentration, while the inhibition zones for 10x concentrated extracts were similar to those produced by the streptomycin control (Fig. 4B).

In general, the streptomycin control had a more potent effect on bacterial isolates than crude extracts of both sponge species at TL concentration, while the effect of sponge crude extracts at $10 \times \mathrm{TL}$ concentration were not much different from those of the streptomycin control (Figs. $3 \& 4$ ). Moreover, the growth of some bacteria such as $\alpha$-Proteobacteria (Carr491, Carr479), Firmicutes (Hkr16), and $\gamma$-Proteobacteria (Carr501, Hke13) was not affected by streptomycin but was inhibited by sponge extracts.

Multifactor ANOVA revealed that the inhibition of bacterial growth in the disc diffusion bioassays with extracts of sponges at TL concentration varied with the geographic location of the bacterial isolates tested (Hong Kong or the Bahamas) and with sponge extract (Callyspongia sp. or C. plicifera) (Table 4). The location, the source of bacteria (interior, exterior and reference) and sponge extracts in combination affected the results of the disk diffusion experiments. At 10× TL concentration of extracts, both the source of bacteria and the extract affected bacterial growth. We found that combinations of factors (the habitat source of bacteria and bacterial geographic origin, as well as the source of bacteria [sponge or reference substrata] and the extracts) affected the results of the disc diffusion experiments at $10 \times \mathrm{TL}$ concentration of extracts.

\section{Larval bioassay}

The extracts of both sponge species affected larval attachment and larval mortality of Hydroides elegans and Balanus amphitrite (Fig. 5). The extracts from Callyspongia sp. and C. plicifera at TL concentration were toxic to larvae of the polychaete $H$. elegans and the barnacle B. amphitrite (Fig. 5B,D). A 100× diluted concentration of both sponge extracts did not show any effect on larval mortality. Only the extracts of Callyspongia plicifera at $10 \times$ dilution inhibited larval attachment of B. amphitrite (Fig. 5A).

\section{DISCUSSION}

In our investigation, the T-RFLP analysis demonstrated that microbial communities associated with Callyspongia sp. and Calyspongia plicifera sponges
Table 4. Multifactor ANOVA. Effects of bacteria source (exterior, interior, and substrata), geographic location (Hong Kong, the Bahamas) and sponge extract (Callyspongia sp. and $C$. plicifera) on the inhibition of bacterial growth. Data were square root transformed prior to analysis $(n=5)$

\begin{tabular}{|lrrrr|}
\hline \multirow{5}{*}{ Effects } & df & MS & $F$ & $\mathrm{p}$ \\
\hline Crude extracts at tissue level concentration \\
Source & 2 & 0.930 & 1.574 & 0.208 \\
Location & 1 & 4.722 & 7.988 & 0.004 \\
Sponge & 1 & 2.722 & 4.606 & 0.032 \\
Source $\times$ Location & 2 & 0.527 & 0.891 & 0.411 \\
Source $\times$ Sponge & 2 & 6.312 & 10.678 & $<0.001$ \\
Species $\times$ Location & 1 & 0.003 & 0.006 & 0.937 \\
Source $\times$ Location $\times$ Sponge & 2 & 3.424 & 5.792 & 0.003 \\
Residual & 618 & 0.591 & & \\
Crude extracts at 10 $\times$ tissue level concentration & \\
Source & 2 & 73.828 & 19.431 & $<0.001$ \\
Location & 1 & 0.897 & 0.236 & 0.627 \\
Sponge & 1 & 18.927 & 4.981 & 0.026 \\
Source $\times$ Location & 2 & 15.468 & 4.071 & 0.018 \\
Source $\times$ Sponge & 2 & 33.335 & 8.773 & 0.0002 \\
Extract $\times$ Location & 1 & 0.054 & 0.014 & 0.905 \\
Source $\times$ Location $\times$ Sponge & 2 & 5.178 & 1.362 & 0.257 \\
Residual & 618 & 3.800 & & \\
\hline
\end{tabular}

were different from microbial communities developed on the reference substrata in close proximity to the sponges. This fact was further supported by the existence of some bacterial isolates specifically associated with sponges. These findings suggest that sponges can directly (by the production of chemical compounds) or indirectly (by having inhibitive symbionts) modify the bacterial communities associated with them. Similar results have been shown in previous experiments with proliferating sponge primmorphs (Thakur et al. 2003). Lee \& Qian $(2003,2004)$ also demonstrated that bacterial isolates and bacterial communities found on the surface of the sponge Mycale adhaerens were different from communities found on inanimate reference surfaces. Further, similar observations were made for internal microbial communities of sponges (Burja \& Hill 2001, Hentschel et al. 2002, Taylor et al. 2004, 2005), indicating that sponges have distinct bacterial communities.

Microbial communities associated with Callyspongia sp. were more diversified than those associated with $C$. plicifera, as the number of T-RFs (ribotypes) from Hong Kong was higher than that from the Bahamas. For the first time we were able to demonstrate clear differences in bacterial communities between 2 congeneric sponges from the West Atlantic (the Bahamas) and the West Pacific (Hong Kong). This contradicts the assumption that similar bacterial communities are associated with sponges from different seas (Hentschel et al. 2002, 2003, Fieseler et al. 2004, Olson \& 

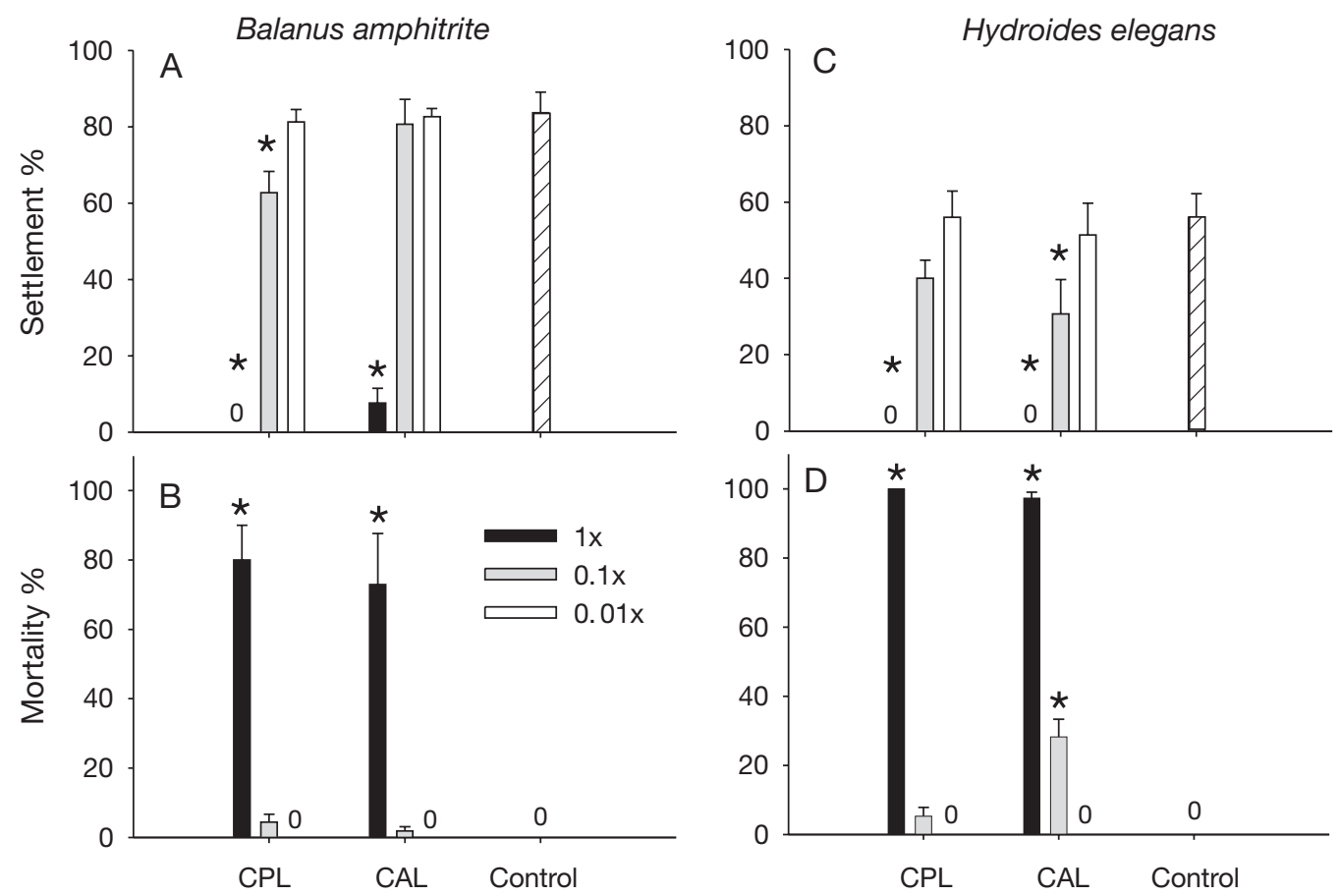

Fig. 5. (A, B) Barnacle Balanus amphitrite and (C, D) polychaete Hydroides elegans larval attachment and mortality in the presence of crude extracts of Callyspongia sp. from Hong Kong (CAL) and C. plicifera from the Bahamas (CPL) at TL (1×), 10-fold dilution $(0.1 \times)$ and 100 -fold dilution $(0.01 \times)$. ${ }^{*}$ Significantly different $(p<0.05)$ from the control (FSW with $3 \%$ DMSO) according to

Dunnett's $t$-test. Results $=$ mean $\pm \mathrm{SE} ; 0=$ no attachment $(\mathrm{A} \& \mathrm{C})$ or no mortality $(\mathrm{B} \& \mathrm{D})$ of larvae in experiments

McCarthy 2005). However, our results are in a good agreement with the findings of Taylor et al. (2005), who also showed that bacterial communities associated with the sponge Cymbastela concentrica from tropical waters differed from those in temperate Australia, whereas bacterial communities over a $500 \mathrm{~km}$ range were similar. Of course, it remains to be explored whether differences in sponge-associated bacterial community structures will also hold for other sponge species from different geographic regions.

GC-MS analysis demonstrated that more than $60 \%$ of the compounds from the Bahamas Callyspongia plicifera and the Hong Kong Callyspongia sp. were similar compared to Halichondria species from the same locations. Taking into account that microbial communities of Callyspongia spp. were different, this finding may suggest that most of the extracted chemical compounds are synthesized by the sponges and that they are specific to Callyspongia spp. Van Soest \& Braekman (1999) suggested referring to these as 'taxonomically distributed compounds'.

What kinds of 'taxonomically distributed compounds' are known for Callispongiidae spp.? Surprisingly, the information about the presence of similar chemical compounds in sponges is limited (Erpenbeck \& van Soest 2005). Most compounds, like peroxidecontaining acids (Toth \& Schmitz 1994), pyridine alka- loids (Wang et al. 1996) and terpenes (Tsukamoto et al. 1997), are unique and isolated only from particular Callyspongia species. In contrast, 3-alkylpiperidine derivatives have a dominant presence in Callyspongia spp. and their distribution may be congruent with the phylogenetic affinities of sponges (Andersen et al. 1996). None of the above-mentioned compounds were found during our experiment. There are 2 possible explanations for this. Firstly, most of the isolated compounds have been identified through biomedical studies; therefore, they may be unique to and present in particular sponge species only. Secondly, the Callyspongia genus contains $>200$ species, which have a paraphyletic or polyphyletic origin according to their molecular phylogeny (van Soest \& Braekman 1999). Therefore, in this large group of sponges, related species may not have exactly the same secondary metabolites. We therefore suggest investigation of the chemical composition and production of secondary metabolites by congeneric species from different geographic locations to test this assumption.

In the disc diffusion bioassay, crude extracts of both Callyspongia species predominantly inhibited the growth of bacteria isolated from the reference surfaces, but inhibited the bacterial isolates from the sponges only to a minor extent, suggesting that bioactive compounds could have played a role in the selec- 
tive retention of bacteria in sponge tissue. Notably, the growth of only 1 out of 20 bacterial isolates from the sponge Mycale adhaerens was affected by sponge extracts (Lee \& Qian 2004), and sponge extracts selectively inhibited bacterial attachment and growth in assays by Kelly et al. (2003). Similarly, Kelman et al. (2001) found that extracts of the sponge Amphimedon viridis did not inhibit the growth of sponge-associated bacteria, but did affect the growth of bacteria isolated from the water column. Extracts of the sponges Pachychalina sp., Acanthella cavernosa, and Xestospongia testudinaria altered bacterial community profiles on hydrogel surfaces, suggesting that the attachment of some bacteria was prevented during the period of experiments with running seawater (Harder et al. 2004). Newbold et al. (1999) reported that different species of Caribbean sponges produced different antibacterial compounds that targeted different bacterial strains. Thus, the specific effects of sponge extracts on surface bacteria indicate a potential role of sponge metabolites in the formation of sponge-specific microbial communities.

The source of bacteria (sponge exterior, interior, or adjacent substrata), the geographic location of bacteria (Hong Kong or the Bahamas), the extracts (Callyspongia sp. or C. plicifera), and a combinations of these factors all had statistically significant effects on the results of the disc diffusion experiments. The present study, for the first time, investigated the effect of sponge extracts on bacterial isolates from congeneric sponge species from different geographic locations. The following studies are the only examples that share similar lines of experimentation with this study: Assmann et al. (2000) found that concentrations of the anti-predator compound sceptrin from the sponges Agelas wiedenmayeri and A. conifera from different locations of the Bahama Islands were different. Green (1977) found that bioactivity and toxicity in the marine sponges Haliclona spp. and Halichondria spp. from different latitudes on the Pacific side of the North American continent were different, indicating that toxicity in sponges increased with decreasing latitude. Green (1977) also found that sponges exposed to predators (fishes) produced a wider range of antifeeding substances. Therefore, it is prudent to expand this sort of comparative study in order to achieve a better understanding of ecological roles of bacteria associated with sponges.

In our experiments, the extracts of Callyspongia $s p$. and C. plicifera at TL concentration and at 10x dilutions were toxic to larvae of the polychaete Hydroides elegans and the barnacle Balanus amphitrite. In fact, toxicity of sponges to marine organisms has been well documented (Becerro et al. 1997, Amsler et al. 2000, Lee \& Qian 2003, Dobretsov et al. 2004, 2005a,b). For instance, spherulous cells of the encrusting sponge Crambe crambe produce toxic guanidine alkaloids with antifouling, antipredation, and allelopathic functions in nature (Beccerro et al. 1997). The sponge Mycale adhaerens inhibits larval attachment of $H$. elegans by excreting toxic waterborne compounds (Lee \& Qian 2003). Conditioned seawater from the sponge Callyspongia (E.) pulvinata is also toxic to the benthic diatom Nitzschia paleacea and larvae of the tube worm H. elegans (Dobretsov et al. 2004). It is possible that similar toxic metabolites exist in other species of Callispongiidae, including the 2 sponge species studied here.

Overall, this study demonstrated that 2 congeneric Callyspongia species from 2 biogeographically different zones accommodated distinct bacterial communities but produced relatively similar secondary metabolites compared to other sponge species. This result should be taken into account in future investigations where a better understanding of sponge microbial associations needs to be developed-including an understanding of their dynamics and potential to produce bioactive metabolites - in order to interpret this invertebrate-microbe association more realistically.

Acknowledgements. This investigation was supported by a Hong Kong RGC grant (HKUST6240/04M) to P.Y.Q. and by the U.S. National Science Foundation Biological Oceanography Program (OCE-0095724) to J.R.P. We thank Ms. Y. K. Tam and Ms. M. Y. Tsoi (Hong Kong) for assistance with community fingerprinting analysis, Mr. J. D. Cowart (USA) for assistance in chemical extraction of sponge tissues, Mrs. Y. Plakhotnikova (Hong Kong) for assistance with bacterial isolation and identification, and Prof. Rob van Soest (Netherlands) for the identification of sponge individuals collected from Hong Kong. We thank Prof. J. Pechenik (USA), Prof. D. Hahn (USA) and Dr. T. Harder (Germany) for their useful comments, and 3 anonymous reviewers who made a significant contribution to the final version of the manuscript. We are grateful to the Captain and Crew of the RV 'Seward Johnson I', and to the Government of the Bahamas for allowing us to conduct scientific research in their territorial waters.

\section{LITERATURE CITED}

Amann RI, Krumholz L, Stahl DA (1990) Fluorescent-oligonucleotide probing of whole cells for determinative, phylogenetic, and environmental studies in microbiology. J Bacteriol 1972:762-770

Amsler CH, Moeller CB, McClintock JB, Iken KB, Baker BJ (2000) Chemical defenses against diatom fouling in Antarctic marine sponges. Biofouling 16:29-45

Andersen RJ, van Soest RWM, Kong F (1996) 3-Alkylpiperidine alkaloids isolated from marine sponges in the order Haplosclerida. In: Pelletier SW (ed) Alkaloids: chemical and biological perspectives, Vol 10. Pergamon Press, Oxford, p 301-355

Assmann M, Lichte E, Pawlik JR, Koeck M (2000) Chemical defenses of the Caribbean sponges Agelas wiedenmayeri and Agelas conifera. Mar Ecol Prog Ser 207:255-262 
Bakus GJ, Targett NM, Schulte B (1986) Chemical ecology of marine organisms: an overview. J Chem Ecol 12: 951-987

Beccerro MA, Uriz MJ, Turon X (1997) Chemically-mediated interactions in benthic organisms: the chemical ecology of Crambe crambe (Porifera Becilosclerida). Hydrobiologia 355:77-89

Beccero MA, Thacker RW, Turon X, Uriz MJ, Paul V (2003) Biogeography of sponge chemical ecology: comparisons of tropical and temperate defenses. Oecologia 135:91-101

Blackwood CB, Marsh T, Kim SH, Paul EA (2003) Terminal restriction fragment length polymorphism data analysis for quantitative comparison of microbial communities. Appl Environ Microbiol 69:926-932

Blunt JW, Copp BR, Munro MHG, Northcote PT, Prinsep MR (2003) Marine natural products. Nat Prod Rep 20:1-131

Bryan JP, Kreider L, Qian PY (1997) Attachment of the polychaete Hydroides elegans on surfaces of the cheilostome bryozoan Bugula neritina: evidence for a chemically mediated relationship. J Exp Mar Biol Ecol 220:171-190

Buchan A, Newell SY, Butler M, Biers EJ, Hollibaugh JT, Moran MA (2003) Dynamics of bacterial and fungal communities on decaying salt marsh grass. Appl Envir Microbiol 69:6676-6687

Burja AM, Hill RT (2001) Microbial symbionts of the Australian Great Barrier Reef sponge, Candidaspongia flabellata. Hydrobiologia 461:41-47

Clarke KR, Warwick RM (1994) Changes in marine communities: an approach to statistical analysis and interpretation. Bourne Press, Bournemouth

Davis A (1998) Antifouling defence in a subtidal guild of temperate zone encrusting invertebrates. Biofouling 12: 305-320

Dobretsov S, Qian PY (2002) Effect of bacteria associated with the green alga Ulva reticulata on marine micro- and macrofouling. Biofouling 18:217-228

Dobretsov S, Dahms HU, Qian PY (2004) Antilarval and antimicrobial activity of waterborne metabolites of the sponge Callyspongia (Euplacella) pulvinata: evidence of allelopathy. Mar Ecol Prog Ser 271:133-146

Dobretsov S, Dahms HU, Qian PY (2005a) Antibacterial and anti-diatom activity of Hong Kong sponges. Aquat Microb Ecol 38:191-201

Dobretsov S, Dahms HU, Tsoi MY, Qian PY (2005b) Chemical control of epibiosis by Hong Kong sponges: the effect of sponge extracts on micro- and macrofouling communities. Mar Ecol Prog Ser 297:119-129

Dunbar J, Ticknor LO, Kuske CR (2001) Phylogenetic specificity and reproducibility and new method for analysis of terminal restriction fragment profiles of 16S rRNA genes from bacterial communities. Appl Envir Microbiol 67: 190-197

Eden PE, Schmidt TM, Blakemore RP, Pace NR (1991) Phylogenetic analysis of Aquaspirillum magnetotacticum using polymerase chain reaction-amplified 16S rRNA-specific DNA. Int J Syst Bacteriol 41:324-325

Erpenbeck D, van Soest RWM (2005) A survey for biochemical synapomorphies to reveal phylogenetic relationships of halichondrid demosponges (Metazoa: Porifera). Biochem Syst Ecol 33:585-616

Faulkner DJ (2000) Marine natural products. Nat Prod Rep 17: 7-55

Fieseler L, Horn M, Wagner M, Hentschel U (2004) Discovery of the novel candidate phylum 'Poritobacteria' in marine sponges. Appl Environ Microb 70:3724-3732

Green G (1977) Ecology of toxicity in marine sponges. Mar Biol 40:207-215
Harder T, Lau SCK, Tam WY, Qian PY (2004) An ecologically realistic method to investigate chemically-mediated defense against microbial epibiosis in marine invertebrates by using TRFLP analysis and natural bacterial populations. FEMS Microbiol Ecol 47:93-99

Hentschel U, Schmid M, Wagner M, Fieseler L, Gernert C, Hacker J (2001) Isolation and phylogenetic analysis of bacteria with antimicrobial activities from Mediterranean sponges Aplysina aerophoba and Aplysina cavernicola. FEMS Microbiol Ecol 35:305-312

Hentschel U, Hopke J, Horn M, Friedrich A, Wagner M, Hacker J, Moore B (2002) Molecular evidence for a uniform microbial community in sponges from different oceans. Appl Environ Microbiol 68:4431-4440

Hentschel U, Fieseler L, Wehrl M, Gernert C, Steinert M, Hacker J, Horn M (2003) Microbial diversity of marine sponges. Mueller WEG (ed) Marine molecular biotechnology. Springer Verlag, Berlin, p59-88

Hill RT (2004) Microbes from marine sponges: a treasure trove of biodiversity for natural product discovery. In: Bull AT (ed) Microbial diversity and bioprospecting. ASM Press, Washington, DC, p 177-190

Kelly S, Jensen PR, Henkel TP, Fenical W, Pawlik JR (2003) Effects of Caribbean sponge extracts on bacterial attachment. Aquat Microb Ecol 31:175-182

Kelman D, Kashman Y, Rosenberg E, Ilan M, Ifrach I, Loya Y (2001) Antimicrobial activity of the reef sponge Amphimedon viridis from the Red Sea: evidence for selective toxicity. Aquat Microb Ecol 24:9-16

Lau SCK, Qian PY (1997) Phlorotannins and related compounds as larval settlement inhibitors of the tube-building polychaete Hydroides elegans. Mar Ecol Prog Ser 159: 217-227

Lau SCK, Mak KKW, Chen F, Qian PY (2002) Bioactivity of bacterial strains from marine biofilms in Hong Kong waters for the induction of larval settlement in the marine polychaete Hydroides elegans. Mar Ecol Prog Ser 226:301-310

Lee OO, Qian PY (2003) Chemical control of bacterial epibiosis and larval attachment of Hydroides elegans in the Red Sponge Mycale adhaerens. Biofouling 19:171-180

Lee OO, Qian PY (2004) Potential control of bacterial epibiosis on the surface of the sponge Mycale adhaerens. Aquat Microb Ecol 34:11-21

Lee S, Malone C, Kemp PF (1993) Use of multiple 16S rRNAtargeted fluorescent probes to increase signal strength and measure cellular RNA from natural planktonic bacteria. Mar Ecol Prog Ser 101:193-201

Luna GM, Dell'Anno A, Danovaro M (2005) DNA extraction procedure: a critical issue for bacterial diversity assessment in marine sediments. Environ Microbiol 8:308-320

Montalvo NF, Mohamed NM, Enticknap JJ, Hill RT (2005) Novel actinobacteria from marine sponges. Antonie van Leeuwenhoek 87:29-36

Newbold RW, Jensen PR, Fenical W, Pawlik JR (1999) Antimicrobial activity of Caribbean sponge extracts. Aquat Microb Ecol 19:279-284

Olson JB, McCarthy PJ (2005) Associated bacterial communities of two deep-water sponges. Aquat Microb Ecol 39:47-55

Pechenik JA, Qian PY (1998) Onset and maintenance of metamorphic competence in the marine polychaete Hydroides elegans Haswell in response to three chemical cues. J Exp Mar Biol Ecol 226:51-74

Rittschof D, Clare AS, Gerhart DJ, Mary A, Bonaventura J (1992) Barnacle in vitro assays for biologically active substances: toxicity and attachment inhibition assays using mass cultured Balanus amphitrite amphitrite Darwin. Biofouling 6:115-122 
Ruetzler K (1985) Associations between Caribbean sponges and photosynthetic organisms. In Ruetzler K (ed) New perspectives in sponge biology. Smithsonian Institution Press, Washington, DC, p 455-466

Santavy DL, Colwell RR (1990) Comparison of bacterial communities associated with the Caribbean sclerosponge Ceratoporella nicholsoni and ambient seawater. Mar Ecol Prog Ser 67:73-82

Shapiro SS, Wilk MB (1965) An analysis of variance test for normality (complete samples). Biometrika 52:591-611

Sponga F, Cavaletti L, Lazzarini A, Borghi I, Ciciliato A, Losi D, Marinelli F (1999) Biodiversity and potentials of marine derived micro-organisms. J Biotechnol 70:65-69

Taylor MW, Schupp PJ, Dahlloef I, Kjelleberg S, Steinberg PD (2004) Host specificity in marine sponge-associated bacteria, and potential implications for marine microbial diversity. Environ Microbiol 6:121-130

Taylor MW, Schupp PJ, de Nys R, Kjelleberg S, Steinberg PD (2005) Biogeography of bacteria associated with the marine sponge Cymbastela concentrica. Environ Microbiol 7:419-493

Thacker RW, Starnes S (2003) Host specificity of the symbiotic cyanobacterium Oscillatoria spongeliae in marine sponges, Dysidea spp. Mar Biol 142:643-648

Thakur NL, Hentschel U, Krasko A, Pabel CT, Anil AC, Müller WEG (2003) Antibacterial activity of the sponge Suberites domuncula and its primmorphs: potential basis for epibac-

Editorial responsibility: Howard Browman (Associate Editorin-Chief), Storebø, Norway terial chemical defense. Aquat Microb Ecol 31:77-83

Thiyagarajan V, Harder T, Qian PY (2002) Relationship between the energy reserve of cyprids and metamorphosis in the barnacle Balanus amphitrite Darwin (Cirripedia; Thoracica). J Exp Mar Biol Ecol 280:79-93

Thoms C, Horn M, Wagner M, Hentschel U, Proksch P (2003) Monitoring microbial diversity and natural product profiles of the sponge Aplysina cavernicola following transplantation. Mar Biol 142:685-692

Toth SI, Schmitz FJ (1994) Two cytotoxic peroxide-containing acids from the New Guinea sponge Callyspongia sp. J Nat Prod 57:123-127

Tsukamoto S, Kato H, Hirota H, Fusetani N (1997) Antifouling terpenes and steroids against barnacle larvae from marine sponges. Biofouling 11:283-291

van Soest RWM, Braekman JC (1999) Chemosystematics of Porifera: a review. Mem Qld Mus 44:569-589

Wang G, Kuramoto M, Uemura D (1996) Three novel antimicrofouling nitroalkyl pyridine alkaloids from Okinawan marine sponge Callyspongia sp. Tetrahedron Lett 37 : 1813-1816

Webster NS, Hill RT (2001) The culturable microbial community of the Great Barrier Reef sponge Rhopaloeides odorabile is dominated by an alpha-Proteobacterium. Mar Biol 138:843-851

Zar JH (1999) Biostatistical analysis, 4th edn. Prentice Hall International, Upper Saddle River, NJ

Submitted: November 11, 2005; Accepted: January 31, 2006 Proofs received from author(s): August 23, 2006 